\title{
Table of treaties
}

\section{In chronological order}

1648 Treaty of Westphalia 35

1814 Treaty of Paris (Defining Treaty of Peace) 4

1864 Geneva Convention for Ameliorating the Condition of the Wounded of Armies in the Field 37, 242

Additional Articles (1868) 37, 242

1868 Declaration of St Petersburg (Explosive Projectiles) 21, 38, 157

1899 Declaration prohibiting Throwing Projectiles and Explosives from Balloons 40, 209

Declaration prohibiting the Use of Projectiles spreading Asphyxiating or Noxious Gases 40, 47

Declaration prohibiting the Use of Bullets which Explode or Flatten in the Human Body 40

Hague Convention II concerning the Laws and Customs of War on Land 41

Hague Convention III for the Adaptation to Maritime Warfare of the Principles of the Geneva Convention, 1864200

1906 Geneva Convention for ameliorating the Conditions of the Wounded and Sick of Armies in the Field 38

1907 Declaration prohibiting the Discharge of Projectiles and Explosives from Balloons 40, 46, 209

Hague Convention II (Opening of Hostilities) 4, 5, 42, 44, 93, 298

Hague Convention IV (Laws and Customs of Warfare on Land) 15, 22, 41, 49, $147,154,159,208,336$

Art. 1308

Art. 3 43, 228, 307, 318-19

Hague Regulations on Land Warfare

Art. $143,309,334$

Art. 3 34, 224

Art. 4 42, 300

Art. 742

Art. 1242

Art. 22 42, 151

Art. 23 42, 43, 100, 149, 153, 157, 167, 170, 173-4, 179, 201, 331, 336, 364 


\section{Table of treaties}

Art. 24171

Art. 25 122-3, 181, 219, 256

Art. 26 182, 256

Art. 27 57, 179, 180, 278

Art. 28256

Art. 29 145, 177

Arts 30-31 145, 176

Art. 32 42, 114

Arts 32-4 113

Art. 35 112, 116

Arts 36-7 106

Art. 40 106, 332

Art. 41307

Art. 43287

Art. 44285

Arts 44-7 256

Art. 46 168, 284, 288

Arts 49-51 288, 289

Art. 52 168, 289

Art. 53 178, 288

Art. 54178

Art. 55289

Art. 56288

Hague Convention V (Rights and Duties of Neutrals in Land Warfare) 42, 44, 140, 294

Arts 7-8 301, 302

Art. 11213,300

Art. 13300

Art. 14301

Arts $17-18303$

Hague Convention VI (Enemy Merchant Ships on the Outbreak of Hostilities) 42, 101, 194

Hague Convention VII (Conversion of Merchant Ships) 193

Hague Convention VIII (Laying of Automatic Submarine Contact Mines) 187, 191

Art. 2204

Art. 3203

Hague Convention IX (Bombardment by Naval Forces) 44, 202

Art. 1122

Art. 6182

Hague Convention X (Adoption to Maritime Warfare of Geneva

Convention Principles) 200, 242

Hague Convention XI (Restrictions on Capture in Maritime War) 190, 199 Arts 5-6 199

Hague Convention XII (International Prize Court) 46

Hague Convention XIII (Rights and Duties of Neutrals in Maritime Warfare) 42, 190, 196, 303

Art. 8272 


\section{Table of treaties}

1919 Treaty of Versailles 5-6

Art. 119159

Art. 227 5, 319

Art. 228 43, 319-20

Covenant of the League of Nations 49

Art. 10105

Art. $116-7$

Art. 167

1922 Treaty of Washington (unratified) on the Use of Submarines and Noxious Gases in Warfare 45, 159

1925 Geneva Protocol prohibiting the Use in War of Asphyxiating, Poisonous or other Gases, and Bacteriological Methods of Warfare 48, 154, 159-60, 333

1928 Pact of Paris (General Treaty for the Renunciation of War, the KelloggBriand Pact) 9-10, 15-16, 95

1929 Geneva Convention for the Amelioration of the Conditions of the Wounded and Sick in Armed Forces in the Field 37, 49, 242

Geneva Convention on the Treatment of Prisoners of War 49-50, 159, 224, 229, 273

Art. 2229

Art. 31230

1930 Treaty of London (unratified) for the Limitation and Reduction of Naval Armaments 45, 197, 243

1936 London Protocol on the Rules of Submarine Warfare 45, 197, 243

1937 Nyon Agreement on Aircraft and Submarine Activity 45, 72, 344

1944 Chicago Convention on International Civil Aviation 209

1945 Charter of the United Nations 11-13, 69

Art. 111,134

Art. 2 78, 205

Art. 2 (4) 11, 190, 205, 371

Art. 2 (5) 298

Art. 2 (6) 96

Art. 2 (7) 86, 343, 350

Art. 25 298, 378

Art. 2712

Arts 41-2 12, 371

Art. 43 371, 379

Art. 47376

Art. $518,11,13,18-19,95,295,377-8,394$

Art. 52378

Art. 53 45, 378

Chapter VII 12, 74, 78, 95, 139, 343, 361, 371, 372

London Agreement and Charter for the Prosecution and Punishment of Major War Criminals 13-14, 50-1

Art. $64,14,45,324,325$

Art. 7 14, 320, 325

Art. 8 51, 320, 338

1946 Convention on the Privileges and Immunities of the United Nations 385

1948 Genocide Convention 52, 97, 333 


\section{Table of treaties}

1949 Geneva Conventions 23, 38, 54

I Wounded and Sick, Armed Forces in the Field (Land Warfare) 53, 342

Art. 1 69, 142

Art. 2 69, 93, 97, 105, 298, 346

Art. $354-6$

Art. 4243,344

Arts 6-7 243

Art. 8273

Art. 11274,313

Art. 12244

Art. 13142

Art. 14 109, 243

Art. 15246

Art. 19248

Art. 21 248, 250

Art. 23120

Art. 27301

Art. 28109

Art. 36 248, 252, 253

Art. 45246

Art. 46311

Art. 47308

Art. 49 56, 303, 321, 326

Art. 50 56, 321, 327

Art. 51310

Art. 52314

II Wounded and Sick, Armed Forces at Sea (Sea Warfare) 53, 190, 200, 242

Art. $169,142,321$

Art. 2 69, 93, 97, 346

Art. 3 54-6

Art. 5244

Arts 6-7 243, 313

Art. 8273

Art. 11 274, 313

Art. 12 201, 244, 247

Art. 13 142, 201

Art. 14201

Arts 14-17 112, 247

Art. 16243

Art. 18 201, 217, 246

Art. 21247

Art. 22 248, 251

Art. 23251

Art. 24248

Art. 25 248, 301

Art. 27214

Art. 28251

Art. 31 201, 251, 253 


\section{Table of treaties}

Art. 35251

Art. 39 252, 253

Arts 44-5 204

Art. 47 246, 311

Art. 48308

Art. 50 56, 303, 321, 326

Art. 51 56, 327

Art. 52 310, 314

Art. 53314

Art. 62306

III Prisoners of War 53, 55, 74, 87, 93, 117, 224, 243, 374

Art. 1 24, 69, 138, 224-5

Art. 2 69, 93, 97, 224, 346

Art. 3 54-6

Art. 4 132, 142, 199, 211, 213, 300

Art. 5 98, 226

Art. 6 117, 136, 176, 231, 237

Art. 7 144, 174, 231, 240

Art. 8233,273

Art. 9233

Art. 10233

Art. 11 233, 274, 313

Art. 12 224, 227, 232

Art. 13 71, 148, 229, 311

Art. 14 227, 228, 231

Art. 16227

Art. 18231

Arts 22-3 228, 235

Art. 25231

Art. 29231

Arts 30-7 235

Art. 30229

Arts 32-3 235

Art. 34228

Art. 35235

Art. 38228

Art. 39 235-6

Art. 40229

Art. 41236

Arts 43-5 227

Art. 44 229, 235

Art. 49 231, 233-6

Art. 50230

Arts 52-6 183, 230

Art. 62 230, 306

Arts 70-4 232

Art. 78 236, 275

Art. 79236 


\section{Table of treaties}

Arts 80-1 237

Art. 82 225, 237

Arts 84-5 238

Art. 86238

Art. 87239

Art. 88 231, 238

Art. 89238

Art. 91240

Arts 95-8 239

Art. 96237

Art. 97231

Arts 100-1 240

Art. 102340

Arts 103-7 239

Art. 105238

Arts 105-6 340

Arts 105-8 324

Art. 109 240, 254

Arts 109-11 227

Art. 110 240, 254

Art. 111240

Art. 115240

Art. 117240

Art. 118 240, 241

Art. 120 104, 230

Art. 121230

Arts 122-3 232

Art. 126233

Art. 127 236, 308

Art. 129 56, 241, 303, 321, 326

Art. 132314

Art. 142306

IV Protection of Civilians 53, 74, 99-100, 105, 139, 225, 363, 365-6, 384

Art. 169,259

Art. 2 69, 92-3, 257, 346

Art. $354-6,116,258$

Art. 4 100, 102, 176, 303, 366

Art. 5257

Art. 6100

Arts 7-8 261, 292

Art. 9 261, 273

Art. 10261

Art. 12 259, 274, 313

Art. 13 292, 311

Arts $14-15$ 120, 121

Art. 23169

Art. 24 276, 290

Arts 24-6 268 


\section{Table of treaties}

Art. 27 111, 259, 262, 288

Arts 29-34 292

Art. 31285

Art. 32262

Art. 33 263, 264, 288, 284, 311

Art. 34259,311

Art. 35111

Arts 35-7 265

Art. 38265

Art. 40 184, 265

Art. 44 266, 267

Art. 47 259, 266

Arts 47-8 257, 264

Art. 49 184, 212, 259, 267, 276, 294, 303

Art. 50290

Art. 51 121, 174, 184, 257, 259, 265, 289

Art. 52259

Art. 53 259, 288-9, 295

Art. 54287

Arts 55-9 290

Arts 59-61 259, 277

Art. 63280

Arts 64-8 270, 291

Arts 66-76 259, 264

Art. 70 102, 270, 291

Arts 71-5 292

Art. 75270

Art. 78292

Art. 80266

Arts 83-98 296

Art. 102278

Arts 106-16 257, 327

Arts $120-1270$

Art. 144308

Art. 146 56, 288, 303, 321, 326

Art. 147 56, 263, 321

Art. 148310

Art. 149 313, 314

Art. 158306

1950 European Convention on Human Rights Art. 15 85, 100

1954 Convention for the Protection of Cultural Property in the Event of Armed Conflict Art. 1 44, 57, 179-80, 219, 278, 288, 329

1958 Geneva Convention on the High Seas Art. 8193

1962 Vienna Convention on Diplomatic Relations 101 Art. 3302

Art. 26112 


\section{Table of treaties}

Art. 30302

Art. 31 112, 302

Art. 44110

Art. 45110

1963 Tokyo Convention on Offences committed on board Aircraft 68

1965 Convention on the Elimination of all Forms of Racial Discrimination 329

1966 International Convention on Civil and Political Rights

Art. 15323

1969 Vienna Convention on the Law of Treaties

Art. 19187

Art. 6071

Arts 62-3 97

1970 Convention on Prohibiting and Preventing the Illicit Import, Export and Transfer of Cultural Property 180

Hague Convention for Suppression of unlawful Seizure of Aircraft 68

1971 Montreal Convention for the Suppression of Unlawful Acts against the Safety of Civil Aviation 68

1972 Convention on the Prohibition of the Development, Production and Stockpiling of Bacteriological (Biological) and Toxin Weapons and their Destruction 61, $160-1,333$

1973 Convention on the Crime of Apartheid 329

Convention on the Prevention and Punishment of Crimes against Internationally Protected Persons 68

1976 Convention on the Prohibition of Military or other Hostile Uses of Environment Modification Techniques 152, 162, 183, 220, 330

1977 Protocol I to the 1949 Geneva Conventions (International Armed Conflicts) 23, $24,38,44$

Art. $168,75,79-80,82,97,132,261,348,387,391$

Art. 397

Art. 5 103, 110, 273

Art. 8 146, 243, 245, 248, 252

Art. 9248

Art. 10245

Art. $11245-6,328$

Art. 12248

Arts $15-17245$

Art. 17247

Art. 20 148, 246, 311

Art. 22200

Art. 24248

Arts 24-31 101, 208

Art. 26 182, 219, 252

Art. 30253

Art. 31253

Art. 33 112, 130, 155, 183

Art. 36 312-13

Art. 37 114, 153, 171, 382

Art. 39 152, 171-2 


\section{Table of treaties}

Art. 40 152, 173, 201

Art. 41 109, 208, 233

Art. 42 177, 215

Art. 43 111, 134, 138, 142, 173, 309

Art. 44 27, 98, 135, 137-8, 142, 261, 328

Art. 45 136, 226, 328

Art. 46 138, 145, 226

Art. 47 132, 139, 303

Art. 48 42, 149

Arts $48-58123$

Arts $48-60212$

Art. 49 42, 47, 101, 118, 149, 171, 181, 184, 195, 202, 205, 208, 212, 218, 394

Art. 51 72, 129, 149, 150, 155, 184, 186, 212, 219, 223, 311, 336

Arts 51-6 118, 154, 264

Arts 51-60 148

Art. 52 118, 150, 154-5, 179, 181, 219, 223, 311, 354, 389

Art. 53 154, 180, 259, 311

Art. 54 154, 168-9, 205-6, 289, 311, 394

Art. 55 72, 118, 153-4, 162, 183, 311, 330, 394

Art. 56 153, 154, 162, 183-5, 220, 311, 394

Art. 57 149, 150, 155, 182-3, 212, 219-20, 223

Art. $58118-19,184$

Art. 59 122-3, 219

Art. $60121-2$

Art. 62281

Art. 66281

Arts $68-71258$

Art. 69290

Arts $72-8258$

Art. 73267,328

Art. 74268

Art. 75 139, 227, 233, 238, 239, 263-4, 292, 311, 322

Art. $7632,231,265,271$

Art. 77 269, 290

Art. 78 276, 290

Art. 79 133, 271

Art. 82 175, 309, 337

Art. 83 40, 175, 308

Art. 85 57, 114, 162, 171, 235, 241, 321, 328-9, 348, 389

Art. $8656,310,333$

Art. 87 175, 310, 333, 337

Arts 88-9 321

Art. 90 63, 313-14

Art. 99306

Art. 10081

Annexe 252 


\section{Table of treaties}

Protocol II Non-international armed conflicts

Art. 1 68, 82, 349, 369

Art. $373,85,350$

Art. 4351,353

Art. 5356,357

Art. 6353,357

Art. 9359

Arts $10-11229,359$

Art. 13 352, 353

Art. 15354

Art. 17355

Art. 18 356,

Art. 19 90, 360

Protocol III, 2005 Emblems 38, 134, 250

1979 International Convention against the Taking of Hostages 68

1980 Convention relating to the Use of certain Conventional Weapons 44, 63-4, 163

Protocol I 63, 163

Protocol II, amended 1996 62-3, 163, 222

Protocol III 27, 64, 157, 165, 221

Protocol IV, 1995 44, 64, 147

1982 UN Convention on the Law of the Sea

Art. 19190

Art. 29193

Art. 34196

Arts 37-54 210

Art. 46196

Art. 88190

Art. 91197

Art. 301190

1989 UN Convention on the Rights of the Child 143, 268

International Convention against the Recruitment, Use, Financing and Training of Mercenaries 141

1990 Treaty on the Final Settlement with respect to Germany 104-5

1993 Statute of the International Criminal Tribunal for the former Yugoslavia 52, 68, 74, 347, 361, 364

Convention on the Prohibition of the Development, Production, Stockpiling and Use of Chemical Weapons and their Destruction 61, 161

1994 Statute of the International Criminal Tribunal for Rwanda 52, 68, 74, 348, 361

Convention on the Safety of United Nations and Associated Personnel 372

1995 Agreement on the Military Aspects of the Bosnia Peace Settlement 73

Paris General Framework for Peace in Bosnia 73

1997 Ottawa Treaty on Land Mines 164, 222

1998 Rome Statute of the International Criminal Court 12, 17, 51-2, 57, 79, 162, 306, 325-6, 327

2001 Convention against the Recruitment, Use and Training of Mercenaries 140-1 